Research Journal of Soil and Water Management 10 (1): 1-7, 2019

ISSN: 2075-1095

(C) Medwell Journals, 2019

\title{
Calculation of Rice Water Requirement for An Giang Province Under the Impacts of Climate Variability
}

\author{
Truong An Dang and Van Hao Lam \\ University of Science VNU-HCM, 227 Nguyen Van Cu Str., 5 District, \\ Ho Chi Minh City, Vietnam
}

\begin{abstract}
The study area is one of the important agricultural areas in the Mekong Delta of Vietnam. It has an important contribution in term of food security and economic development in Vietnam. In recent years, this area has seriously impacted by salinization, drought due to the impact of climate change leading to the irrigation water scarce for agricultural production. Therefore, the accurate estimation of irrigation water requirements is very necessary and especially in the context of the climate variability. The aim of this study was to define irrigation water requirement, net irrigation requirements and to conduct efficient irrigation schedule for improved irrigation practices order to provide information necessary in taking decisions on irrigation management under the impacts of climate change. This study is conducted applying the CORPWAT crop model based on meteorological factors recorded from 2004-2015. The simulated results showed that the crop water demand of the Winter-Spring, Summer-Autumn and crop water demand cropsvarying from $0.0-176.8 \mathrm{~mm} / \mathrm{dec}$. The high crop water demand was recorded in the Winter-Spring, Summer-Autumn crops (from 593.4-827.8 mm) and lower was observed in the Autumn-Winter crop $(236.3 \mathrm{~mm})$. The highest Crop Water Demand (CWD) values of Winter-Spring, Summer-Autumn crop was occurred from the mid-second decade to the end of the third decade and the lowest CWD value was close to zero on the four decades to the mid-sixth decade of the Autumn-Winter crop. The simulation results showed that CORPWAT crop model can be successfully applied to define reference Evapotranspiration $\left(\mathrm{ET}_{0}\right)$, actual Evapotranspiration $\left(\mathrm{ET}_{\mathrm{C}}\right)$, Effective Rainfall (ER), CWD and irrigation conditions with reasonable accuracy.
\end{abstract}

$\underline{\text { Key words: Irrigation water, Crop Model, effective rainfall, water scarce, climate change, food security }}$

\section{INTRODUCTION}

The rainfall is one of the major factors which impacts on crop production, especially agricultural production (Shah et al., 2015; Feng et al., 2007). In recent years, under the impact of climate change, the distribution of rainfall at the regions of the world is changing (APN., 2010; MNRE., 2016). While rainfall plays a very important role and is considered as the main factor for irrigation activities which significant influence on farmer's production. In the study area, crops irrigation water is based on local rainfall and fresh water which come from the upper Mekong River (MNRE., 2016). In the dry season, water level at almost irrigation channels is low reduced and it is created favorable conditions for salt water from the sea to pervade deep into the irrigation channels which hinders irrigation for planting crop. Therefore, the increases of irrigation water by rainfall during dry seasonal period is considered essential for agricultural production activities in the context of water scarcity due to drought and salinization, they are threatening for the agricultural activities (MNRE., 2016; Wani et al., 2017). Croitoru et al. considered rainfall as one of two important factors which can directly be reflected by climate change. Feddema and Freire (2001) concluded that global warming will affect water sources and agricultural production activities. Their results showed that water lost to runoff may increase deficits during rainy seasons, thus, causing crops to suffer higher water stress during the dry season. Adeniran et al. (2010) reported that the growth and development stages of crops depend on rainfall factor. They showed that too little/much rainfall will affect the agricultural activities and crop yields. In the agricultural sector, irrigation water is considered as the key factor, therefore, rainfall is considered as an important source to supply soil moisture. Each planting crop has different irrigation water requirement and it is varied according to the time, season. The rate of water uptake required to the plant growth processes in the stages of planting development depends on irrigation water, soil properties, cultivars and meteorological factors (Smith, 1992; Feng et al., 2007).

Corresponding Author: Truong An Dang, University of Science VNU-HCM, 227 Nguyen Van Cu Str., 5 District, Ho Chi Minh City, Vietnam 
In this study, the CORPWAT crop model is selected to simulate the rice water requirement for three plating crops including Winter-Spring, Summer-Autumn and Autumn-Winter based on the meteorological factors namely sunshine, temperature, humidity, rainfall.

\section{MATERIALS AND METHODS}

Study area: The study area is located in the lower Mekong Delta of Vietnam with a total area $3536 \mathrm{~km}^{2}$ and it has the Eastern border with Dong Thap Province, the North and Northwest borders the provinces of Kandal and Takeo of Cambodia with a border of nearly $104 \mathrm{~km}$, the Southwest of Kien Giang Province and the South border with Can Tho City. It lies from $10^{\circ} 12-10^{\circ} 57^{\prime} \mathrm{N}$ Latitudes and $104^{\circ} 46-105^{\circ} 35^{\prime} \mathrm{E}$ Longitudes (Fig. 1). It has a complex terrain with elevations ranging from 0.5-2.5 $\mathrm{m}$ above mean sea level (Vu et al., 2008; Danh and Khai, 2014). In the study area, agricultural is considered the main sector with two or three rice planting crops per year based on fresh water come from the Mekong River and local rainfall (Vu et al., 2008; Danh and Khai, 2014). It has the lowest annual average rainfall in the region with values approximately $1353-1516 \mathrm{~mm}$ (Fig. 2). According to Adeniran et al. (2010), the critical phases of plant development in the tropical area mainly depend on rainfall factor. Their results also showed that crop water demand depends on not only soil type, growing seasons, the plant varieties but also climatic conditions.
Model description: CORPWAT crop model is conducted to simulate crop water requirement, to design irrigation schedules and management of irrigation schedules by the land and water development division of food and agriculture organization. In addition, this model also allows the conduction of recommendations for improved irrigation practices, planning of irrigation schedules under varying irrigation water conditions and different weather conditions (Smith, 1992). The Penman-Monteith method is used in the CORPWAT Model to define potential Evaporation $\left(\mathrm{ET}_{0}\right)$ while actual Evaporation $\left(\mathrm{ET}_{\mathrm{C}}\right)$ is defined based on $\mathrm{ET}_{0}$ and $\mathrm{K}_{\mathrm{C}}$ the crop coefficient (Adeniran et al., 2010; Saravanan and Saravanan, 2014). First, the CORPWAT Model define $\mathrm{ET}_{0}$ on a 10-days basis as:

$$
\mathrm{ET}_{\mathrm{O}}=\frac{0.408 \Delta\left(\mathrm{R}_{\mathrm{n}}-\mathrm{G}\right)+\gamma \frac{900}{\mathrm{~T}+273} \mathrm{u}_{2}\left(\mathrm{e}_{\mathrm{s}}-\mathrm{e}_{\mathrm{a}}\right)}{\Delta+\gamma\left(1+0.34 \mathrm{u}_{2}\right)}
$$

Where:

$\mathrm{ET}_{0}=$ Reference evaporation $\left(\mathrm{mm} /\right.$ day $\left.^{-1}\right)$

$\mathrm{R}_{\mathrm{n}}=$ The net radiation at the crop surface $\left(\mathrm{Mjdaym}^{-2}\right)$

$\mathrm{G}=$ Soil heat flux density $\left(\mathrm{Mjdaym}^{-2}\right)$

$\mathrm{T}=$ Mean daily air temperature at $2.0 \mathrm{~m}$ height $\left({ }^{\circ} \mathrm{C}\right)$

$\mathrm{u}_{2}=$ Wind speed at $2.0 \mathrm{~m}$ height $\left(\mathrm{m} / \mathrm{sec}^{-1}\right)$

$\mathrm{e}_{\mathrm{s}}=$ The saturation vapor pressure $(\mathrm{kPa})$

$\mathrm{e}_{\mathrm{a}}=$ Actual vapor pressure $(\mathrm{kPa})$

$\Delta=$ The slope of the vapor pressure curve $\left(\mathrm{kPa}^{\circ} \mathrm{C}^{-1}\right)$

$\mathrm{c} \quad=$ Psychrometric constant $\left(\mathrm{kPa}^{\circ} \mathrm{C}^{-1}\right)$

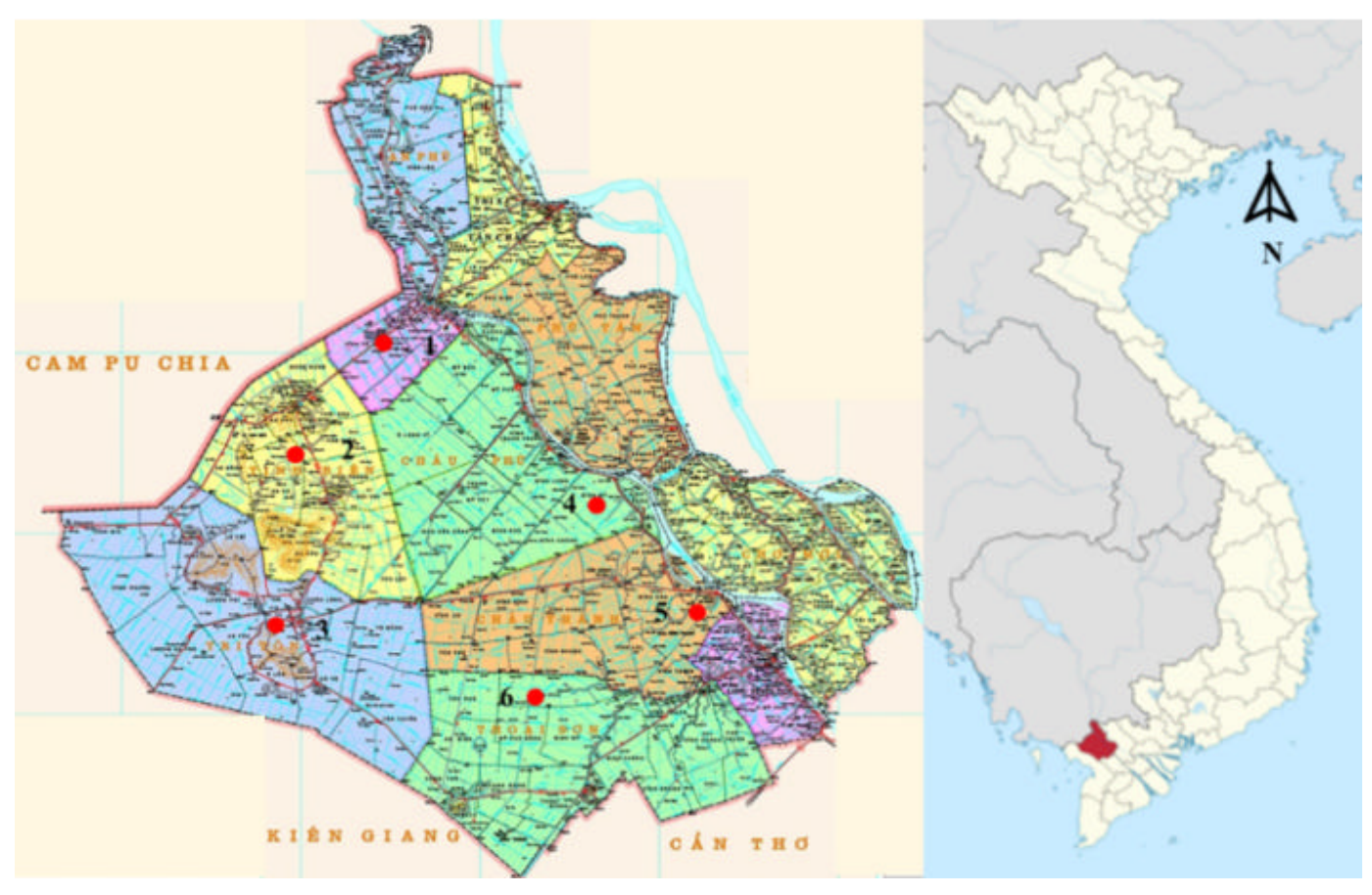

Fig. 1: Illustration of weather stations in the study area 
Res. J. Soil and Water Manage., 10 (1): 1-7, 2019

Table 1: Monthly values of climatic parameters for the study area

\begin{tabular}{|c|c|c|c|c|c|c|c|}
\hline \multirow[b]{2}{*}{ Months } & \multicolumn{2}{|c|}{ Temperature $\left({ }^{\circ} \mathrm{C}\right)$} & \multirow{2}{*}{$\begin{array}{l}\text { Humidity (\%) } \\
\left(\mathrm{MJ} / \mathrm{m}^{2} / \text { day }\right)\end{array}$} & \multirow[b]{2}{*}{ Wind $\left(\mathrm{ms}^{-1}\right)$} & \multirow[b]{2}{*}{ Sun shines (h) } & \multirow[b]{2}{*}{ Net radiation } & \multirow[b]{2}{*}{ Rainfall (mm) } \\
\hline & Min & Max & & & & & \\
\hline$\overline{\text { Jan }}$ & 16.9 & 34.8 & 78 & 2.5 & 6.8 & 17.4 & 5.30 \\
\hline Feb & 19.5 & 36.6 & 77 & 3.3 & 7.2 & 19.2 & 1.24 \\
\hline Mar & 17.4 & 37.5 & 76 & 3.2 & 6.9 & 19.8 & 19.70 \\
\hline Apr & 22.8 & 38.4 & 78 & 3.1 & 7.1 & 20.5 & 75.80 \\
\hline May & 23.1 & 38.7 & 80 & 3.0 & 6.4 & 19.0 & 184.30 \\
\hline Jun & 22.7 & 39.6 & 84 & 4.7 & 6.1 & 18.2 & 104.90 \\
\hline Jul & 22.5 & 35.3 & 84 & 4.3 & 5.2 & 17.0 & 175.40 \\
\hline Aug & 21.4 & 35.5 & 84 & 4.7 & 5.2 & 17.3 & 209.70 \\
\hline Sep & 22.8 & 34.9 & 84 & 4.2 & 5.4 & 17.5 & 258.90 \\
\hline Oct & 21.9 & 33.7 & 83 & 2.7 & 5.8 & 17.3 & 228.40 \\
\hline Nov & 20.6 & 33.9 & 80 & 2.4 & 6.8 & 17.6 & 144.50 \\
\hline Dec & 17.5 & 33.8 & 79 & 2.5 & 6.4 & 16.4 & 29.80 \\
\hline
\end{tabular}

Table 2: Crop calendar for rice crops planted in the study area

\begin{tabular}{lccc}
\hline Crop/Seasons & Crop length (day) & Sowing date & Harvesting date \\
\hline Winter-Spring & 115 & 15-Dec & 29-Mar \\
Summer-Autumn & 115 & 15-Apr & 28-Jul \\
Autumn-Winter & 115 & 15-Aug & 27-Nov \\
\hline
\end{tabular}

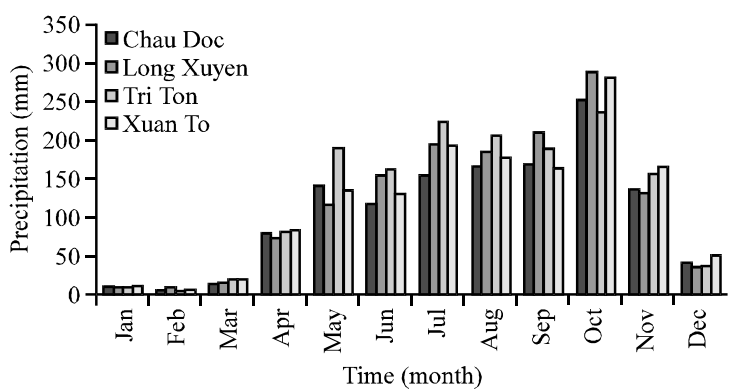

Fig. 2: Annual mean rainfall in the study area in the period 2004-2015

Then, actual evapotranspiration is defined by Eq. 2 :

$$
\mathrm{ET}_{\mathrm{C}}=\mathrm{ET}_{\mathrm{O}} * \mathrm{~K}_{\mathrm{C}}
$$

Where:

$\mathrm{ET}_{\mathrm{C}}=$ The actual evapotranspiration by the crop $\left(\mathrm{mm} /\right.$ day $\left.^{-1}\right)$

$\mathrm{K}_{\mathrm{C}}=$ The crop coefficient at a specific growth stage and it depends on the type of planting crop and change in the the development stage of a crop

To define irrigation water demand for each plating crop it is first essential to define the Effective Rainfall (ER) over the cultivated area (Arku et al., 2012; Bhat et al., 2012). The ER can be defined by Eq. 3 (Table 1-4):

$$
\mathrm{ER}=\mathrm{P}_{\text {month }} \frac{125-0,2 * \mathrm{P}_{\text {month }}}{125}
$$

where, $\mathrm{ER}$ and $\mathrm{P}_{\text {month }}$ are effective rainfall $(\mathrm{mm})$ and is the total rainfall $(\mathrm{mm})$; finally, crop water demand for each crop can be calculated Eq. 4 :
Table 3: Planting and harvesting dates, growing and crop growth stage

\begin{tabular}{|c|c|c|c|c|c|c|c|c|}
\hline \multirow{2}{*}{ Crop/Season } & \multicolumn{4}{|c|}{ Crop coefficient $\left(\mathrm{K}_{\mathrm{C}}\right)$} & \multicolumn{4}{|c|}{ Growth stages (days) } \\
\hline & LP & I & $\mathrm{D}$ & $\mathrm{L}$ & \multicolumn{4}{|c|}{ 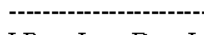 } \\
\hline Winter-Spring & 030 & 050 & 105 & 070 & 10 & 10 & 65 & 30 \\
\hline Summer-Autumn & 1.05 & 1.20 & 1.73 & 1.15 & 10 & 10 & 65 & 30 \\
\hline Autumn- Winter & 1.05 & 1.15 & 1.69 & 1.10 & 10 & 10 & 65 & 30 \\
\hline \multicolumn{9}{|c|}{$\begin{array}{l}\mathrm{LP}=\text { Land Preparation stage; } \mathrm{I}=\text { Initial stage; } \mathrm{D}=\text { Development stage; } \\
\mathrm{M}=\text { Mid-season stage; } \mathrm{L}=\text { Late season stage and } \mathrm{K}_{\mathrm{C}}=\text { crop coefficient }\end{array}$} \\
\hline \multicolumn{9}{|c|}{$\underline{\text { Table 4: Relevant soil characteristics }}$} \\
\hline \multicolumn{5}{|l|}{ Soil descriptions } & \multicolumn{4}{|c|}{ Values } \\
\hline \multicolumn{5}{|c|}{ Maximum rain infiltration rate } & \multicolumn{4}{|c|}{$105(\mathrm{~mm} /$ day $)$} \\
\hline \multicolumn{5}{|l|}{ Plowing depth } & \multicolumn{4}{|c|}{$20(\mathrm{~cm})$} \\
\hline \multicolumn{5}{|c|}{ Maximum water depth } & \multicolumn{4}{|c|}{$70(\mathrm{~cm})$} \\
\hline \multicolumn{5}{|c|}{ Water availability at planting } & \multicolumn{4}{|c|}{$5(\mathrm{~mm})$} \\
\hline \multicolumn{5}{|c|}{ Maximum rooting depth } & \multicolumn{4}{|c|}{$90(\mathrm{~cm})$} \\
\hline \multicolumn{5}{|c|}{ Maximum percolation rate after puddling } & \multicolumn{4}{|c|}{407 (mm/day) } \\
\hline \multicolumn{5}{|c|}{ Critical depletion for puddle cracking } & \multicolumn{4}{|c|}{104} \\
\hline \multicolumn{5}{|l|}{ Drainable porosity } & \multicolumn{4}{|c|}{$13(\%)$} \\
\hline \multicolumn{5}{|c|}{ Initial soil moisture depletion } & \multicolumn{4}{|c|}{0} \\
\hline \multicolumn{5}{|c|}{ Initial available soil moisture } & \multicolumn{4}{|c|}{$140(\mathrm{~mm} / \mathrm{m})$} \\
\hline \multicolumn{5}{|c|}{ Total available soil moisture } & \multicolumn{4}{|c|}{$140(\mathrm{~mm} / \mathrm{m})$} \\
\hline
\end{tabular}
coefficient $\left(\mathrm{K}_{\mathrm{C}}\right)$

$$
\mathrm{Q}=\sum_{\mathrm{i}=0}^{\mathrm{n}} \mathrm{A}_{\mathrm{i}}\left(E \mathrm{ET}_{\mathrm{c}}-\mathrm{ER}\right)^{*} 10
$$

Where:

$\mathrm{Q}=$ Crop water requirement $\left(\mathrm{m}^{3}\right.$ day $\left.^{-1}\right)$

$\mathrm{I}=$ Crop index

$\mathrm{A}_{\mathrm{i}}=$ The crop planted area (ha)

$\mathrm{ET}_{\mathrm{C}}=$ Crop evapotranspiration $\left(\mathrm{mm} /\right.$ day $\left.^{-1}\right)$

Input data: To calculate crop water demand, climate data and cropping patterns were required. Where input data for simulating $\mathrm{ET}_{0}$ including temperature (maximum, minimum), relative humidity, wind speed, solar radiation, sunshine duration, rainfall. The meteorological data was collected from the Southern Regional Hydro-Meteorological Center of the Vietnam during for a period of 12 years (2004-2015).

In addition, detail crop calendar for rice crops planted in the study area is also shown in Table 2. Three main growing seasons in the year including Winter-Spring, Summer-Autumn and Autumn-Winter with crop coefficient $\left(\mathrm{K}_{\mathrm{c}}\right)$, growth stages, crop length, sowing 
and harvesting date for various crops is shown in Table 3 .

In this study, the soil characteristics are predominantly silly-clay mix clay (Table 4). The soil $\mathrm{pH}$ about 4.0 showing the soil is mostly acidic which means that the soils available have high potentials for retaining plant nutrients.

\section{RESULTS AND DISCUSSION}

Reference and actual evapotranspiration: The calculation results of the $\mathrm{ET}_{0}$ of three rice crops showed that the $\mathrm{ET}_{0}$ varies in the range of $3.7-5.0 \mathrm{~mm} /$ day. The $\mathrm{ET}_{0}$ increases gradually approximately from $3.99 \mathrm{~mm} /$ day in January to the peak value of $5.16 \mathrm{~mm} /$ day in April. Then it decreases gradually $3.73 \mathrm{~mm} /$ day in December. The high $\mathrm{ET}_{\text {。 }}$ occurred in May to July as saw in Fig. 3 and it can be explained by the change in air temperature because of the high air temperature and low rainfall in this period.

The monthly variation of $\mathrm{ET}_{0}$ indicates that sowing time can affect significantly CWD for a particular type of crop. The $\mathrm{Et}_{0}$ values varied greatly through three crops and the $\mathrm{Et}_{0}$ value was recorded, approximately $124.9 \mathrm{~mm} / \mathrm{month}$ in the Autumn-Winter crop. While, the highest $\mathrm{ET}_{0}$ values was recorded $155.07 \mathrm{~mm} /$ month in the April of the Summer-Autumn crop and the lowest Et values were recorded $115.67 \mathrm{~mm} / \mathrm{month}$ in the January of the Winter-Spring crop (Fig. 3). The reduction of the ET。 values in the Winter-Spring crop because of the lower air temperature and increase rainfall in this period. The results obtained from the 15-year climatic data were used in the CORPWAT 8.0 to determine the $\mathrm{ET}_{0}$ for the study area. The results show that $\mathrm{ET}_{0}$ was lowest during the rainy season to highest during the Summer season. The calculated values of $\mathrm{Et}_{0}$ at the peak is $6.08 \mathrm{~mm} /$ day at the beginning stage, slightly reduced at growing stage $5.20 \mathrm{~mm} /$ day, at mid-stage reaches $3.58 \mathrm{~mm} /$ day and at the last stage reaches $1.36 \mathrm{~mm} /$ day. The main cause of this decrease is due to an increase of rainfall.

Figure 4 shows that the average $\mathrm{ET}_{\mathrm{C}}$ of Winter-Spring, Summer-Autumn and Autumn-Winter crops were approximately $5.29,5.91$ and $5.06 \mathrm{~mm} /$ day, respectively. Total of the field $\mathrm{ET}_{\mathrm{C}}$ of Winter-Spring, Summer-Autumn and Autumn-Winter crops was calculated $634.9,717.4$ and $615.3 \mathrm{~mm} / \mathrm{crop}$, respectively.

Effective Rainfall (ER): The simulated results of the ER are shown in Fig. 5. Results showed that the ER in the study area varied from $0.0-184 \mathrm{~mm} / \mathrm{month}$. The maximum ER was recorded $184 \mathrm{~mm} / \mathrm{month}$ in October. This can be explained by low air temperature and the rainy season in

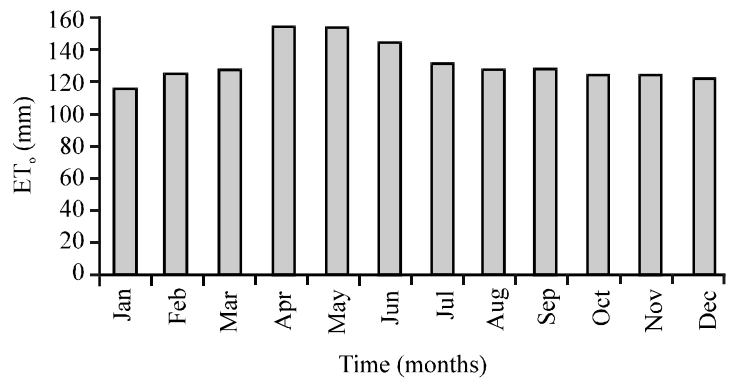

Fig. 3: Simulation results of $\mathrm{ET}_{0}$ with time

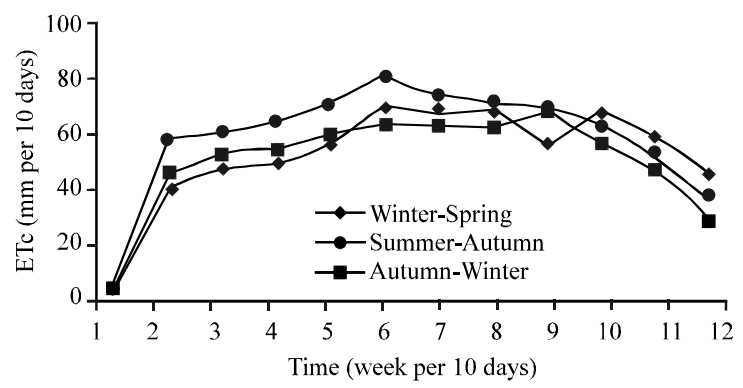

Fig. 4: Calculation results of $\mathrm{ET}_{\mathrm{C}}$ from three rice crops

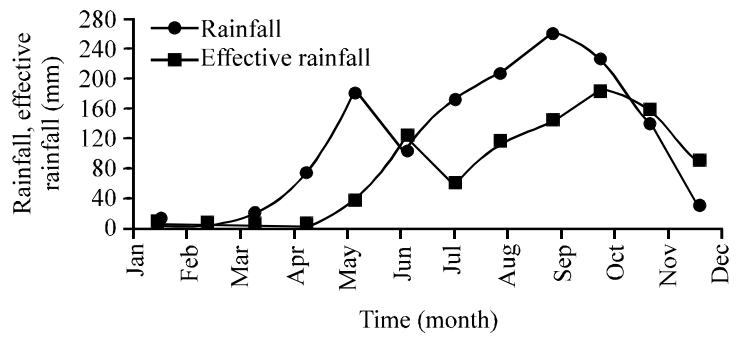

Fig. 5: Simulation results of ER and rainfall with time

this period. Whereas the ER values were close to zero from January-April. Its decline reduction maybe explained by the high air temperature and low rainfall during the Winter-Spring crop.

Standardized Precipitation Index (SPI): According to McKee et al. (1993), the SPI used as the classification system to define drought intensities. Figure 6 showed the drought intensities in the study area for the period 1984-2015. The analyzed results of the SPI showed that the drought occurred in the study area from 2012-2015. The SPI is continuously negative and reaches an intensity from -0.47 to -0.73 in the year 2012,2013 , respectively and conditions further deteriorated in the year 2014, 2015 when SPI reaches from -1.15 to -1.67 corresponding to the rainfall deficit reached 28.9 and $38.7 \%$ (Fig. 6), respectively (moderate and severe drought conditions) (FAO., 2016; Lee and Dang, 2018). 
Res. J. Soil and Water Manage., $10(1): 1-7,2019$

Table 5: Evapotranspiration and irrigation requirement for three crops

\begin{tabular}{|c|c|c|c|c|c|c|c|c|c|c|}
\hline \multirow[b]{2}{*}{ Day } & \multirow[b]{2}{*}{ Stage } & \multicolumn{3}{|c|}{$\mathrm{ET}_{\mathrm{C}}(\mathrm{mm})$} & \multicolumn{3}{|c|}{$\mathrm{ER}(\mathrm{mm})$} & \multicolumn{3}{|c|}{ CWD (mm) } \\
\hline & & WS & SA & $\mathrm{AW}$ & WS & SA & AW & WS & SA & $\mathrm{AW}$ \\
\hline 5 & LP & 4.0 & 5.3 & 4.3 & 0.8 & 0.7 & 4.5 & 80.0 & 81.3 & 80.3 \\
\hline 10 & I & 40.3 & 58.2 & 45.9 & 0 & 9.6 & 47.5 & 153.9 & 174.1 & 62.3 \\
\hline 30 & D & 154.2 & 196.7 & 168.5 & 0.2 & 105 & 175.5 & 154.1 & 91.7 & 1.7 \\
\hline 35 & $\mathrm{M}$ & 206 & 226.1 & 188.9 & 0 & 76.6 & 172.3 & 206 & 149.4 & 16.6 \\
\hline 30 & $\mathrm{~L}$ & 230.5 & 223.5 & 200.4 & 1.5 & 126.8 & 130.3 & 228.6 & 90.5 & 63.5 \\
\hline Total & & 634.9 & 717.4 & 615.3 & 2.57 & 318.4 & 531.9 & 827.8 & 593.4 & 236.3 \\
\hline
\end{tabular}

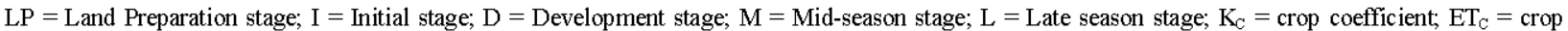
Evapotranspiration; $\mathbb{R}=$ Irrigation Requirement; WS = Winter-Spring; $\mathrm{SA}=$ Summer-Autumn and $\mathrm{AW}=$ Autumn-Winter

Table 6: Simulation of Winter-Spring crop under irrigated condition

\begin{tabular}{|c|c|c|c|c|c|c|c|c|}
\hline Date & Days & Stage & Rain (mm) & Percol (mm) & Depl. SM (mm) & Net Gift (mm) & Loss (mm) & Depl. SAT (mm) \\
\hline 10-Dec & -4 & LP & 0 & 0 & 1 & 76.0 & 0 & 26.0 \\
\hline 11-Dec & -3 & LP & 0 & 56.5 & 2 & 61.6 & 0 & 11.6 \\
\hline 13-Dec & -1 & LP & 2.8 & 6.3 & 2 & 51.9 & 0 & 1.9 \\
\hline 18-Dec & 4 & I & 0 & 4.7 & 0 & 95.0 & 20 & -5.0 \\
\hline 27-Dec & 13 & D & 2.2 & 4.7 & 0 & 96.5 & 20 & -3.5 \\
\hline 05-Jan & 22 & $\mathrm{D}$ & 0 & 4.7 & 0 & 102.8 & 20 & 2.8 \\
\hline 13-Jan & 30 & $\mathrm{D}$ & 0.5 & 4.7 & 0 & 97.2 & 20 & -2.8 \\
\hline 21-Jan & 38 & $\mathrm{D}$ & 0 & 4.7 & 0 & 103.2 & 20 & 3.2 \\
\hline 28-Jan & 45 & $\mathrm{M}$ & 0 & 4.7 & 0 & 96.8 & 20 & -3.2 \\
\hline 04-Feb & 52 & $\mathrm{M}$ & 0 & 4.7 & 0 & 98.7 & 20 & -1.3 \\
\hline $11-\mathrm{Feb}$ & 59 & $\mathrm{~L}$ & 0 & 4.7 & 0 & 99.9 & 20 & -0.1 \\
\hline 18 -Feb & 66 & $\mathrm{~L}$ & 0 & 4.7 & 0 & 101.7 & 20 & 1.7 \\
\hline 25 -Feb & 73 & $\mathrm{~L}$ & 0 & 4.7 & 0 & 102.4 & 20 & 2.4 \\
\hline 04-Mar & 80 & $\mathrm{~L}$ & 0 & 4.7 & 0 & 99.7 & 20 & -0.3 \\
\hline 11-Mar & 87 & $\mathrm{~L}$ & 0 & 4.7 & 0 & 98.0 & 20 & -2.0 \\
\hline 19-Mar & 95 & $\mathrm{~L}$ & 0 & 4.7 & 0 & 100.9 & 20 & 0.9 \\
\hline 28-Mar & 104 & $\mathrm{~L}$ & 0 & 4.7 & 0 & 97.5 & 20 & -2.5 \\
\hline 29-Mar & End & L & 0 & 4.7 & 0 & - & - & - \\
\hline
\end{tabular}
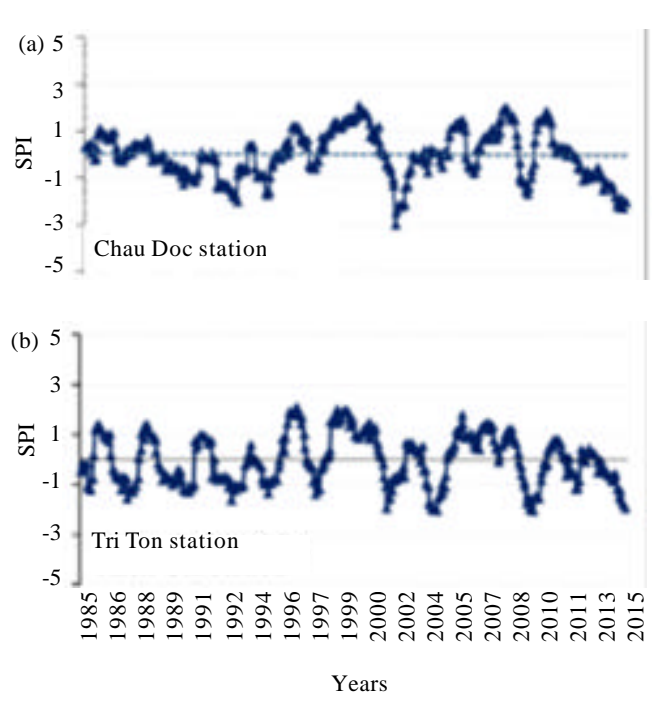

Fig. 6: a,b) Illustration of SPI at some stations in the study area (Lee and Dang, 2018)

Crop Water Demand (CWD): The analyzed results showed that the CWD in the An Giang Province varying from $0.0-176.8 \mathrm{~mm} / \mathrm{dec}$. The results showed that the CWD for the Winter-Spring, Summer-Autumn crops (approximately from 593.4-827.8 mm/crop) were higher the Autumn-Winter crop (236.3 mm/crop)

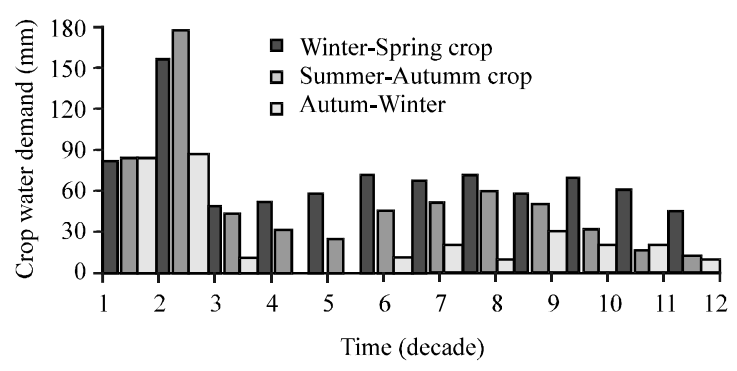

Fig. 7: Illustration of crop water demand for Winter-Spring, Summer-Autumn and AutumnWinter in the study area

(Table 5). The average CWD values of Winter-Spring, Summer-Autumn and Autumn-Winter crops were varying from $18.88 \mathrm{~mm} / \mathrm{dec}$ from $69.77 \mathrm{~mm} / \mathrm{dec}$. The highest CWD values of Winter-Spring, Summer-Autumn crop was recorded from the mid-second decade to the end of the third decade and the lowest CWD value was close to zero (from the four decades to the mid-sixth decade) of the Autumn-Winter crop (Fig. 7) (Table 6).

Irrigation conditions: Irrigation is very required when rainfall is not sufficient to compensate for the water lost by evapotranspiration and percolation. The calculation results of irrigated conditions, depletion of saturation for 
Res. J. Soil and Water Manage., 10 (1): 1-7, 2019

Table 7: Simulation of Summer-Autumn crop under irrigated condition

\begin{tabular}{|c|c|c|c|c|c|c|c|c|}
\hline Date & Days & Stage & Rain (mm) & Percol (mm) & Depl. SM (mm) & Net gift (mm) & Loss (mm) & Depl. SAT (mm) \\
\hline 10-Apr & -4 & LP & 0 & 0 & 2 & 76.0 & 0 & 26.0 \\
\hline 11-Apr & -3 & LP & 0 & 56.5 & 0 & 63.8 & 0 & 13.8 \\
\hline 14-Apr & 0 & LP & 0 & 8.8 & 0 & 61.7 & 0 & 11.7 \\
\hline 20-Apr & 6 & I & 0 & 4.7 & 0 & 102.0 & 30 & 2.0 \\
\hline 30-Apr & 16 & $\mathrm{D}$ & 0 & 4.7 & 0 & 102.5 & 30 & 2.5 \\
\hline 11-May & 27 & $\mathrm{D}$ & 0 & 4.7 & 0 & 104.2 & 30 & 4.2 \\
\hline 21-May & 37 & $\mathrm{D}$ & 0 & 4.7 & 0 & 100.7 & 30 & 0.7 \\
\hline 30-May & 46 & M & 0 & 4.7 & 0 & 97.7 & 30 & -2.3 \\
\hline 08-Jun & 55 & M & 0 & 4.7 & 0 & 99.1 & 30 & -0.9 \\
\hline 15-Jun & 62 & M & 0 & 4.7 & 0 & 99.4 & 30 & -0.6 \\
\hline 22-Jun & 69 & $\mathrm{~L}$ & 0 & 4.7 & 0 & 100.9 & 30 & 0.9 \\
\hline 30-Jun & 77 & $\mathrm{~L}$ & 0 & 4.7 & 0 & 104.7 & 30 & 4.7 \\
\hline 11-Jul & 88 & $\mathrm{~L}$ & 0 & 4.7 & 0 & 102.4 & 30 & 2.2 \\
\hline 22-Jul & 99 & $\mathrm{~L}$ & 0 & 4.7 & 0 & 99.4 & 30 & -0.6 \\
\hline 28-Jul & End & $\mathrm{L}$ & 0 & 0 & 0 & - & - & - \\
\hline
\end{tabular}

Table 8: Simulation of Autumn-Winter crop under irrigated condition

\begin{tabular}{|c|c|c|c|c|c|c|c|c|}
\hline Date & Days & Stage & Rain (mm) & Percol (mm) & Depl. SM (mm) & Net gift (mm) & $\operatorname{Loss}(\mathrm{mm})$ & Depl. SAT (mm) \\
\hline 10-Aug & -4 & LP & 0 & 0 & 1 & 76.0 & 0 & 26.0 \\
\hline 11-Aug & -3 & LP & 0 & 56.5 & 0 & 62.3 & 0 & 12.3 \\
\hline 16-Aug & 2 & I & 0 & 4.7 & 0 & 103.2 & 40 & 3.2 \\
\hline 22-Aug & 8 & I & 0 & 4.7 & 0 & 96.4 & 40 & -3.6 \\
\hline 01-Sep & 18 & $\mathrm{D}$ & 0 & 4.7 & 0 & 99.1 & 40 & -0.9 \\
\hline 12-Sep & 29 & $\mathrm{D}$ & 0 & 4.7 & 0 & 102.2 & 40 & 2.2 \\
\hline 22-Sep & 39 & $\mathrm{D}$ & 0 & 4.7 & 0 & 105.1 & 40 & 5.1 \\
\hline 01-Oct & 48 & M & 0 & 4.7 & 0 & 96.8 & 40 & -3.2 \\
\hline 11-Oct & 58 & M & 0 & 4.7 & 0 & 98.5 & 40 & -1.5 \\
\hline 21-Oct & 68 & M & 0 & 4.7 & 0 & 99.3 & 40 & -0.7 \\
\hline 31-Oct & 78 & $\mathrm{~L}$ & 0 & 4.7 & 0 & 104.3 & 40 & 4.3 \\
\hline 11-Nov & 89 & $\mathrm{~L}$ & 0 & 4.7 & 0 & 103.0 & 40 & 3.0 \\
\hline 21-Nov & 99 & $\mathrm{~L}$ & 0 & 4.7 & 0 & 100.4 & 40 & 0.4 \\
\hline 27-Nov & End & $\mathrm{L}$ & 0 & 0 & 0 & - & - & - \\
\hline
\end{tabular}

each stage is carried out for various crops. The primary objective of irrigation scheduling calculation is to apply water at the right period and in the enough amount. In other words it applied at fixed interval per stage. The irrigation requirement and conditions calculated over a specific period as shown in Table 6-8.

\section{CONCLUSION}

The development stage and mid-season of three rice crops indicating that $\mathrm{ET}_{\mathrm{C}}$ is higher than $\mathrm{ET}_{0}$ and leading to an increased crop water demand in the development and mid-season stages. The simulation results analysis showed that in both conditions rainfed and irrigated, the largest yield reduction occurred in stage three developmental stages. The results obtained from the study can be used as a guide to farmers whom can apply the amount and frequency of irrigation water for the crops. The results will enhance understanding of crop water demand which will consequently help improve the productivity. The much longed for the attainment of stability in food security, reduction in poverty.

The model CORPWAT can appropriately predict $\mathrm{ET}_{0}$, effective rainfall, crop water demand and irrigation conditions caused by crop water deficit which makes this model as a good tool for irrigation planning, irrigation management and sowing calendar.

\section{ACKNOWLEDGEMENTS}

This research is funded by Vietnam National University Ho Chi Minh City (VNU-HCM) under grant number C2018-18-05 project entitled "Calculating crop water requirement for agricultural production in the Mekong River Delta under the influence of climate variability". In addition, I wish to express my sincere thanks to the anonymous reviewers for their helpful comments which helped me to improve this manuscript.

\section{REFERENCES}

APN., 2010. Climate change in Southeast Asia and assessment on impact, vulnerability and adaptation on rice production and water resource. Asia-Pacific Network, Chiang Mai University, Thailand. http://www.apngcr.org/resources/ files/ original/a329d606191 a4bcf135e5de5bac7712d.pdf 
Adeniran, K.A., M.F. Amodu, M.O. Amodu and F.A. Adeniji, 2010. Water requirements of some selected crops in Kampe dam irrigation project. Aust. J. Agric. Eng., 1: 119-125.

Arku, A.Y., S.M. Musa and A.L.E. Mofoke, 2012. Determination of water requirements for irrigating hibiscus (Rosa Sinensis) in Maiduguri metropolis. J. Applied Phytotechnol. Environ. Sanitation, 1: 37-42.

Bhat, N.R., V.S. Lekha, M.K. Suleiman, B. Thomas and S.I. Ali et al., 2012. Estimation of water requirements for young date palms under arid climatic conditions of Kuwait. World J. Agric. Sci., 8: 448-452.

Danh, V.T. and H.V. Khai, 2014. Using a risk cost-benefit analysis for a sea dike to adapt to the sea level in the Vietnamese Mekong river Delta. Climate, 2: 78-102.

FAO., 2016. El Nino Event in Vietnam: Agriculture, Food Security and Livelihood need Assessment in Response to Drought and Salt Water Intrusion. Food and Agriculture Organization, Rome, Italy, Pages: 600 .

Feddema, J.J. and S. Freire, 2001. Soil degradation, global warming and climate impacts. Clim. Res., 17: 209-216.

Feng, Z., D. Liu and Y. Zhang, 2007. Water requirements and irrigation scheduling of Spring maize using GIS and CropWat model in Beijing-Tianjin-Hebei region. Chin. Geogr. Sci., 17: 56-63.

Lee, S.K. and T.A. Dang, 2018. Spatio-temporal variations in meteorology drought over the Mekong River Delta of Vietnam in the recent decades. Paddy Water Environ., 1: 1-10.
MNRE., 2016. Climate change scenarios and sea level rise for Vietnam. Ministry of New and Renewable Energy Government Ministry, New Delhi, India.

McKee, T.B., N.J. Doesken and J. Kleist, 1993. The relationship of drought frequency and duration to time scales. Proceedings of the 8th Conference on Applied Climatology Vol. 17, January 17-22, 1993, American Meteorological Society, Boston, Massachusetts, USA., pp: 179-183.

Saravanan, K. and R. Saravanan, 2014. Determination of water requirements of main crops in the tank irrigation command area using CROPWAT 8.0. Intl. J. Interdiscip. Multi. Stud., 1: 266-272.

Shah, P.V., R.N. Mistry, J.B. Amin, A.M. Parmar and M.R. Shaikh, 2015. Irrigation scheduling using cropwat. Intl. J. Adv. Res. Eng. Sci. Technol., 2: 1-10.

Smith, M., 1992. CROPWAT: A Computer Program for Irrigation Planning and Management (FAO Irrigation and Drainage Paper 46). Food and Agriculture Organization of the United Nation, Rome, Italy, ISBN-13: 9789251031063, Pages: 126.

Vu, D.T., T. Yamada and H. Ishidaira, 2008. Assessing the impact of sea level rise due to climate change on seawater intrusion in Mekong Delta, Vietnam. Water Sci. Technol., 77: 1632-1639.

Wani, J.M., V.K. Sarda and S.K. Jain, 2017. Assessment of trends and variability of rainfall and temperature for the district of mandi in Himachal Pradesh, India. Slovak J. Civ. Eng., 25: 15-22. 